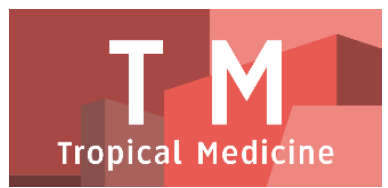

PAPER - OPEN ACCESS

Optimasi Fase Gerak Kromatografi Cair Kinerja Tinggi Pada Penetapan Kadar Parasetamol, Gliseril Guaiakolat, Klorfeniramin Maleat, dan Fenilefrin Hcl Dalam Sediaan Tablet Secara Simultan

Author : Ellora Ellora

DOI $\quad: 10.32734 /$ tm.v1i1.80

Paper Page : $224-229$

Volume 1 Issue 1-2018 TALENTA Conference Series: Tropical Medicine (TM)

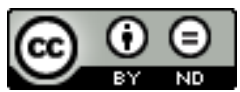

This work is licensed under a Creative Commons Attribution-NoDerivatives 4.0 International License.

Published under licence by TALENTA Publisher, Universitas Sumatera Utara
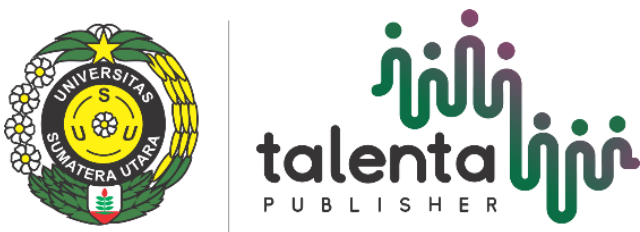


\title{
Optimasi Fase Gerak Kromatografi Cair Kinerja Tinggi Pada Penetapan Kadar Parasetamol, Gliseril Guaiakolat, Klorfeniramin Maleat, dan Fenilefrin Hcl Dalam Sediaan Tablet Secara Simultan
}

\author{
Ellora $^{\mathrm{a}, *}$, Effendy De Lux Putra ${ }^{\mathrm{b}}$, Ginda Haro $^{\mathrm{c}}$ \\ a,b,c Fakultas Farmasi, Universitas Sumatera Utara, Medan 20155, Indonesia \\ tassaella_dds@yahoo.co.id
}

\begin{abstract}
Abstrak
Di pasaran, terdapat berbagai sediaan obat yang mengkombinasikan dua atau lebih zat aktif dalam satu sediaan, salah satunya adalah obat flu yang mengandung parasetamol, klorfeniramin maleat, gliseril guaiakolat dan fenilefrin hidroklorida. Penelitian ini bertujuan untuk menetapkan kadar keempat campuran zat aktif tersebut secara simultan karena analisis keempat campuran zat aktif tersebut belum ditemukan baik di Farmakope Indonesia maupun di United States Pharmacopoeia. Penelitian dilakukan dengan mengoptimasi berbagai jenis campuran fase gerak yaitu metanol dengan buffer fosfat $\mathrm{pH} 4,1$; metanol dengan buffer fosfat $\mathrm{pH} 4,3$ dan metanol dengan buffer fosfat $\mathrm{pH} 4,6$. Selain itu juga dilakukan optimasi berbagai perbandingan fase gerak yaitu 30:70; 40:60; 50:50; 60:40 dan 70:30. Hasil penelitian menunjukkan bahwa kombinasi fase gerak metanol:buffer fosfat pH 4,3 dengan perbandingan fase gerak 60:40; laju alir $1 \mathrm{ml} / \mathrm{menit}$ dan dideteksi pada panjang gelombang $263 \mathrm{~nm}$ dapat digunakan untuk menetapkan kadar parasetamol, klorfeniramin maleat, gliseril guaiakolat dan fenilefrin hidroklorida secara KCKT. Hasil kadar pada sediaan tablet Supraflu® memenuhi persyaratan yaitu diperoleh kadar fenilefrin $\mathrm{HCl}$, parasetamol, gliseril guaiakolat dan klorfeniramin maleat berturutturut adalah $99,2362 \% \pm 0,4493 \% ; 96,0242 \% \pm 0,2180 \% ; 97,9870 \% \pm 0,7435 \%$ dan $101.4191 \% \pm 0,7106 \%$.
\end{abstract}

Kata Kunci: fenilefrin $\mathrm{HCl}$, parasetamol, gliseril guaiakolat, klorfeniramin maleat, KCKT

\section{Pendahuluan}

Dalam bidang farmasi, pemeriksaan mutu obat mutlak diperlukan agar obat dapat sampai pada titik tangkapnya dan memberikan efek terapi yang dikehendaki dengan kadar yang tepat sehingga perlu adanya kontrol kualitatif dan kuantitatif zat berkhasiat dalam sediaan obat. Kombinasi dekongestan, antihistamin, ekspektoran dan analgesik sangat luas digunakan pada pengobatan influenza. Salah satu kombinasi obat flu yang terdapat dipasaran adalah kombinasi dari parasetamol, fenilefrin $\mathrm{HCl}$, klorfeniramin maleat dan gliseril guaiakolat. Contoh sediaannya adalah Supraflu.

Di industri farmaseutikal modern, kromatografi cair kinerja tinggi (KCKT) merupakan peralatan analitik yang paling utama dan sempurna dalam seluruh tingkat penelitian, pengembangan, dan produksi obat [2]. Dilihat dari FI Edisi IV juga, kromatografi cair kinerja tinggi merupakan metode penetapan kadar obat yang paling banyak digunakan. Metode kromatografi cair kinerja tinggi mempunyai beberapa keuntungan dibandingkan metode analisis lain, diantaranya: kolom dapat digunakan kembali, memiliki berbagai jenis detektor, waktu analisis umumnya relatif singkat, ketepatan yang relatif tinggi, ketelitian yang relatif tinggi dan dapat digunakan untuk menganalisis kebanyakan sebagian besar senyawa kimia [4]. Untuk mendapatkan hasil analisis yang baik, maka perlu dilakukan 
optimasi. Optimasi metode KCKT dilakukan untuk mendapatkan pemisahan yang lebih baik, analisis lebih cepat, meningkatkan sensitifitas dan menghemat biaya. Optimasi dilakukan terhadap beberapa variabel diantaranya perbandingan fase gerak, kecepatan alir fase gerak, fase diam atau kolom [3]. Pada penelitian ini akan dilakukan optimasi untuk mencari kondisi terbaik dalam hal menganalisis parasetamol, fenilefrin $\mathrm{HCl}$, klorfeniramin maleat dan gliseril guaiakolat, dimana fase gerak yang akan digunakan merupakan campuran metanol dan suatu buffer dengan $\mathrm{pH}$ tertentu.

Berdasarkan hal tersebut di atas, peneliti tertarik untuk menggunakan kromatografi cair kinerja tinggi (KCKT) untuk penetapan kadar kombinasi keempat campuran obat yaitu parasetamol, klorfeniramin maleat, fenilefrin $\mathrm{HCl}$ dan gliseril guaiakolat dalam sediaan tablet Supraflu ${ }^{\circledR}$ yang dilakukan secara simultan.

\section{Metode Panelitian}

\subsection{Alat dan Bahan}

Alat KCKT dengan detektor UV, kolom VP-ODS, alat spektrofotometer UV-Vis, pH meter, sonikator, timbangan analitik, vacuum pump, cellulose nitrate membrane filter $0,5 \mu \mathrm{m}$; polytetrafluoroethylene (PTFE) membrane filter 0,5 $\mu \mathrm{m}$, labu tentukur, pipet volume, gelas ukur, serta alat-alat gelas lain sesuai dengan kebutuhan.

Bahan-bahan yang digunakan adalah metanol grade for HPLC (E.Merck®), akuabides (Laboratorium Penelitian Fakultas Farmasi USU), Parasetamol BPFI, Gliseril Guaiakolat BPFI, Fenilefrin HCl, dan Klorfeniramin Maleat BPFI, Tablet Supraflu ${ }^{\circledR}$ (PT Kimia Farma).

\subsection{Pembuatan Larutan asam ortofosfat $10 \mathrm{mM}$}

Sejumlah $0,34 \mathrm{ml}$ asam ortofosfat $85 \%$ dimasukkan ke dalam labu $500 \mathrm{ml}$. larutan diencerkan dengan penambahan akuabides sampai garis tanda.

\subsection{Pembuatan Larutan Buffer fosfat $\mathrm{pH} 4,1 ; \mathrm{pH} 4,3 ; \mathrm{pH} 4,6$}

Ditimbang seksama sejumlah 1,3601 g KH2PO4 anhidrat. Masukkan labu $1000 \mathrm{ml}$ dan ditambah akuabides sampai garis tanda. Larutan kemudian dipindahkan ke beaker gelas dan ditambah asam ortofosfat $10 \mathrm{mM}$ sedikit demi sedikit sampai diperoleh $\mathrm{pH}$ 4,1 + 0,1 menggunakan $\mathrm{pH}$ meter [5]. Larutan buffer fosfat kemudian disaring dengan membran penyaring nitrat selulosa $0,5 \mu \mathrm{m}$ dan disonikasi menggunakan alat sonikator selama 30 menit.

Ditimbang seksama sejumlah 1,3601 g KH2PO4 anhidrat. Masukkan labu $1000 \mathrm{ml}$ dan ditambah akuabides sampai garis tanda. Larutan kemudian dipindahkan ke beaker gelas dan ditambah asam ortofosfat $10 \mathrm{mM}$ sedikit demi sedikit sampai diperoleh $\mathrm{pH}$ 4,3 + 0,1 menggunakan $\mathrm{pH}$ meter [5]. Larutan buffer fosfat kemudian disaring dengan membran penyaring nitrat selulosa $0,5 \mu \mathrm{m}$ dan disonikasi menggunakan alat sonikator selama 30 menit.

Ditimbang seksama sejumlah 1,3601 g KH2PO4 anhidrat. Masukkan labu $1000 \mathrm{ml}$ dan ditambah akuabides sampai garis tanda. Larutan kemudian dipindahkan ke beaker gelas dan ditambah asam ortofosfat $10 \mathrm{mM}$ sedikit demi sedikit sampai diperoleh $\mathrm{pH}$ 4,6 + 0,1 menggunakan $\mathrm{pH}$ meter [5]. Larutan buffer fosfat kemudian disaring dengan membran penyaring nitrat selulosa $0,5 \mu \mathrm{m}$ dan disonikasi menggunakan alat sonikator selama 30 menit.

\subsection{Pembuatan larutan induk baku parasetamol, gliseril guaikolat, fenilefrin hidroklorida dan klorfeniramin maleat.}

Ditimbang seksama sejumlah $50 \mathrm{mg}$ baku parasetamol (BPFI), dimasukkan ke dalam labu tentukur $25 \mathrm{~mL}$, dilarutkan dan diencerkan dengan akuabides sampai garis tanda sehingga diperoleh larutan dengan konsentrasi 2000 $\mu \mathrm{g} / \mathrm{ml}$ (LIB I).

Ditimbang seksama sejumlah $50 \mathrm{mg}$ baku gliseril guaiakolat (BPFI), dimasukkan ke dalam labu tentukur 250 $\mathrm{mL}$, dilarutkan dan diencerkan dengan akuabides sampai garis tanda sehingga diperoleh larutan dengan konsentrasi $200 \mu \mathrm{g} / \mathrm{ml}$ (LIB I). 
Ditimbang seksama sejumlah $50 \mathrm{mg}$ baku fenilefrin hidroklorida, dimasukkan ke dalam labu tentukur $25 \mathrm{~mL}$, dilarutkan dan diencerkan dengan akuabides sampai garis tanda sehingga diperoleh larutan dengan konsentrasi 2000 $\mu \mathrm{g} / \mathrm{ml}$ kemudian dipipet $1,5 \mathrm{ml}$ dimasukkan ke dalam labu $100 \mathrm{ml}$, diencerkan dengan akuabides sampai garis tanda dan diperoleh konsentrasi $30 \mu \mathrm{g} / \mathrm{ml}$ (LIB I).

Ditimbang seksama sejumlah $50 \mathrm{mg}$ baku klorfeniramin maleat (BPFI), dimasukkan ke dalam labu tentukur 250 $\mathrm{mL}$, dilarutkan dan diencerkan dengan akuabides sampai garis tanda sehingga diperoleh larutan dengan konsentrasi $200 \mu \mathrm{g} / \mathrm{ml}$ kemudian dipipet $4 \mathrm{ml}$ dimasukkan ke dalam labu $100 \mathrm{ml}$, diencerkan dengan akuabides sampai garis tanda dan diperoleh konsentrasi $8 \mu \mathrm{g} / \mathrm{ml}$ (LIB I).

\subsection{Pembuatan larutan baku campur (LBC)}

Dipipet $10 \mathrm{ml}$ masing-masing LIB 1 dari larutan parasetamol, gliseril guaiakolat, fenilefrin hidroklorida dan klorfeniramin maleat kemudian dimasukkan dalam labu ukur $50 \mathrm{ml}$, dicukupkan dengan akuabides sampai garis tanda (LBC). Diperoleh konsentrasi parasetamol $400 \mu \mathrm{g} / \mathrm{ml}$, konsentrasi gliseril guaiakolat $40 \mu \mathrm{g} / \mathrm{ml}$, konsentrasi fenilefrin hidroklorida $6 \mu \mathrm{g} / \mathrm{ml}$ dan konsentrasi klorfeniramin maleat $1,6 \mu \mathrm{g} / \mathrm{ml}$.

Dipipet 7,5 ml dari LBC, dimasukkan ke dalam labu ukur $10 \mathrm{ml}$, dicukupkan dengan akuabides sampai garis tanda. Diperoleh konsentrasi parasetamol $300 \mu \mathrm{g} / \mathrm{ml}$, konsentrasi gliseril guaiakolat $30 \mu \mathrm{g} / \mathrm{ml}$, konsentrasi fenilefrin hidroklorida $4,5 \mu \mathrm{g} / \mathrm{ml}$ dan konsentrasi klorfeniramin maleat $1,2 \mu \mathrm{g} / \mathrm{ml}$.

Dipipet 5,0 ml dari LBC, dimasukkan ke dalam labu ukur $10 \mathrm{ml}$, dicukupkan dengan akuabides sampai garis tanda. Diperoleh konsentrasi parasetamol $200 \mu \mathrm{g} / \mathrm{ml}$, konsentrasi gliseril guaiakolat $20 \mu \mathrm{g} / \mathrm{ml}$, konsentrasi fenilefrin hidroklorida $3 \mu \mathrm{g} / \mathrm{ml}$ dan konsentrasi klorfeniramin maleat $0,8 \mu \mathrm{g} / \mathrm{ml}$.

Dipipet 2,5 ml dari LBC, dimasukkan ke dalam labu ukur $10 \mathrm{ml}$, dicukupkan dengan akuabides sampai garis tanda. Diperoleh konsentrasi parasetamol $100 \mu \mathrm{g} / \mathrm{ml}$, konsentrasi gliseril guaiakolat $10 \mu \mathrm{g} / \mathrm{ml}$, konsentrasi fenilefrin hidroklorida $1,5 \mu \mathrm{g} / \mathrm{ml}$ dan konsentrasi klorfeniramin maleat $0,4 \mu \mathrm{g} / \mathrm{ml}$.

Dipipet 12,5 ml dari LBC, dimasukkan ke dalam labu ukur $100 \mathrm{ml}$, dicukupkan dengan akuabides sampai garis tanda. Diperoleh konsentrasi parasetamol $50 \mu \mathrm{g} / \mathrm{ml}$, konsentrasi gliseril guaiakolat $5 \mu \mathrm{g} / \mathrm{ml}$, konsentrasi fenilefrin hidroklorida $0,75 \mu \mathrm{g} / \mathrm{ml}$ dan konsentrasi klorfeniramin maleat $0,2 \mu \mathrm{g} / \mathrm{ml}$.

\subsection{Analisis Kuantitatif Campuran Parasetamol, Klorfeniramin Maleat, Fenilefrin $\mathrm{HCl} \quad$ dan Gliseril} Guaiakolat dalam Sediaan Tablet

Ditimbang 20 buah tablet dan digerus hingga homogen. Ditimbang serbuk setara dengan $2 \mathrm{mg}$ klorfeniramin maleat. Serbuk dimasukkan ke dalam labu tentukur $100 \mathrm{ml}$, dilarutkan dan diencerkan sampai garis tanda kemudian dipipet $2 \mathrm{ml}$ dimasukkan ke dalam labu tentukur $50 \mathrm{ml}$ dan diencerkan sampai garis tanda. 


\section{Hasil dan Pembahasan}

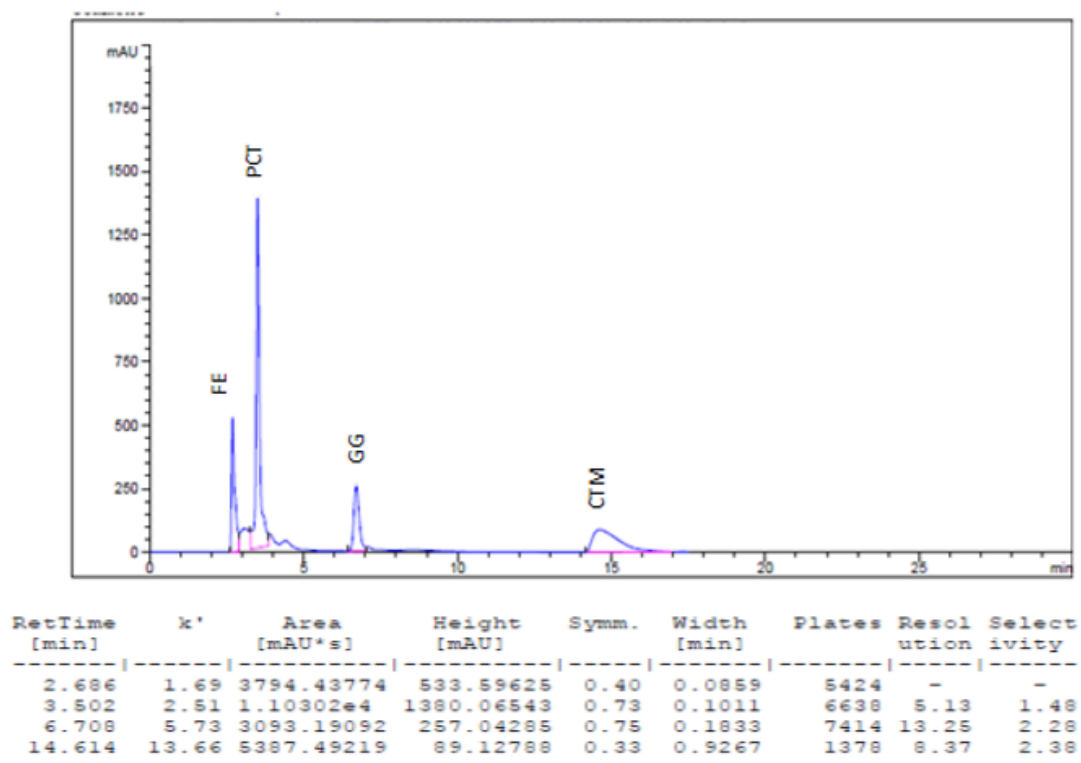

Fig. 2. Hasil kromatogram menggunakan fase gerak metanol:buffer fosfat $\mathrm{pH} 4,1$ dengan perbandingan 60:40

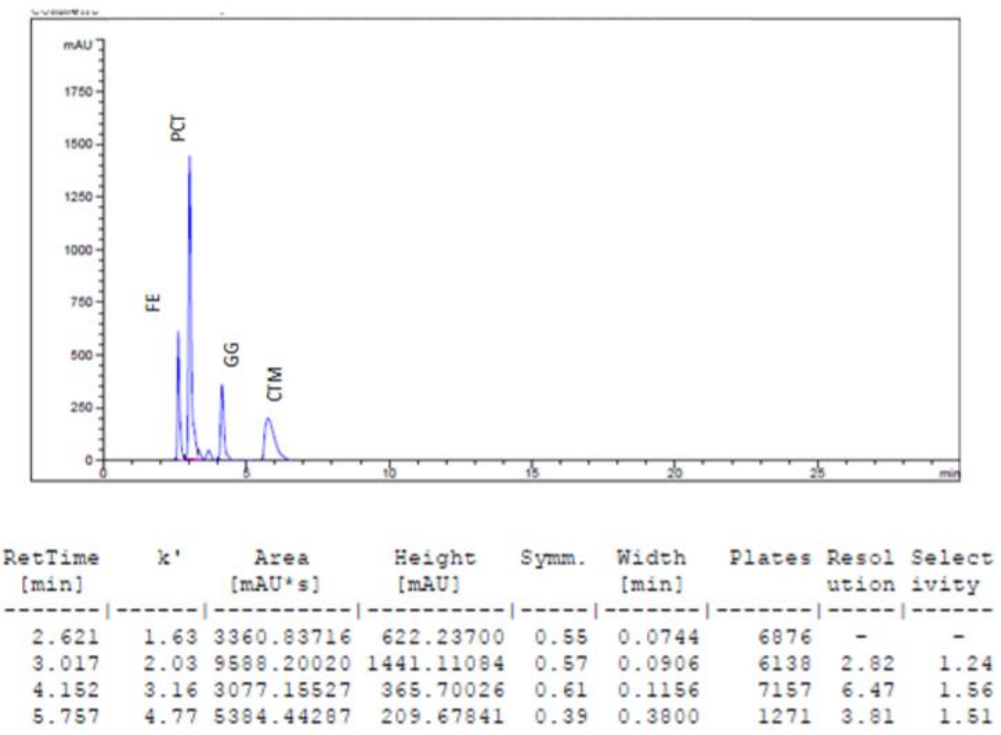

Fig. 1.Hasil kromatogram menggunakan fase gerak metanol:buffer fosfat $\mathrm{pH} 4,3$ dengan perbandingan 60:40 


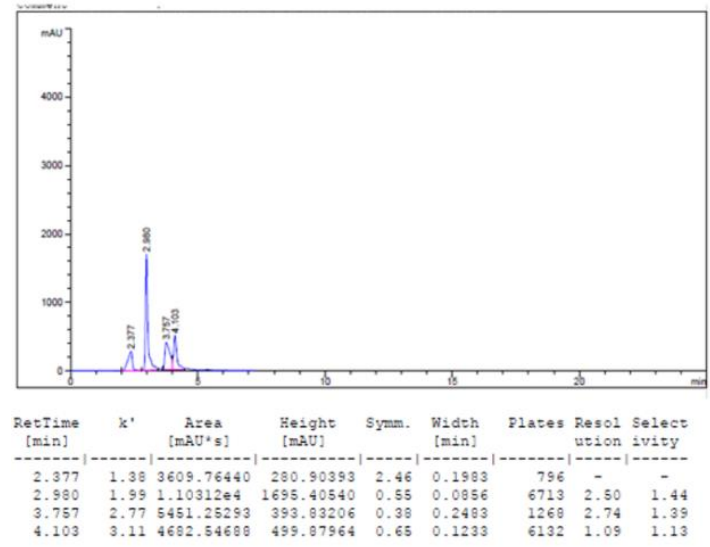

Fig. 3. Hasil kromatogram menggunakan fase gerak metanol:buffer fosfat pH 4,6 dengan perbandingan 60:40

\subsection{Pembuatan Kurva Kalibrasi}

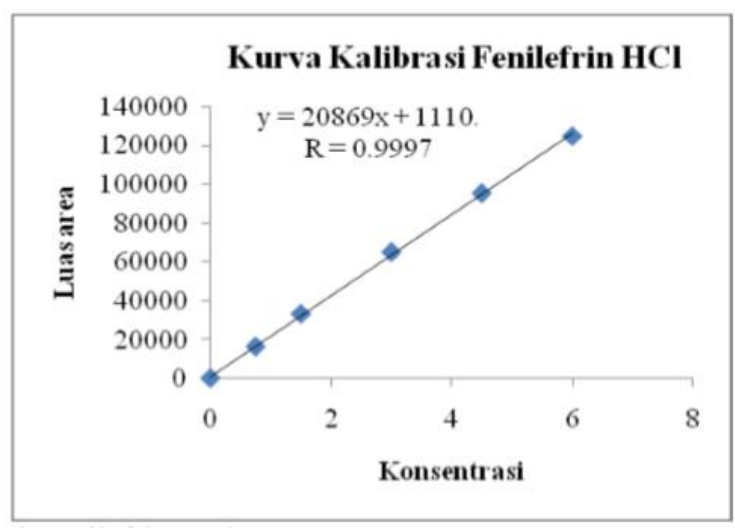

Fig. 4. Kurva Kalibrasi Fenilefrin $\mathrm{HCl}$

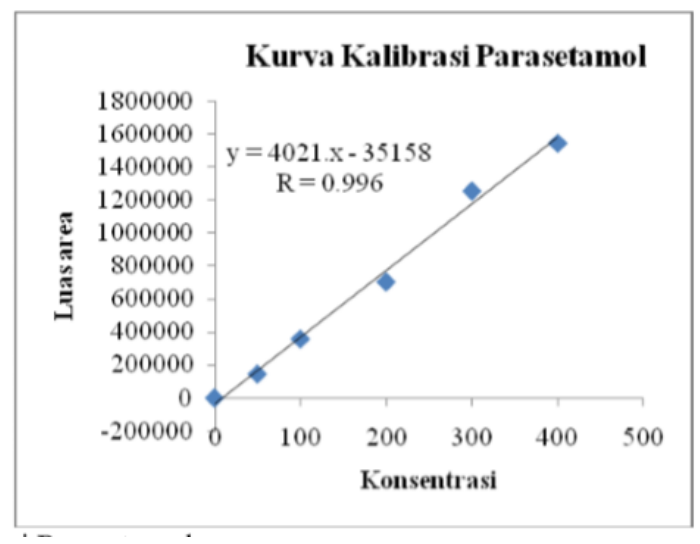

Fig. 5. Kurva Kalibrasi Parasetamol 


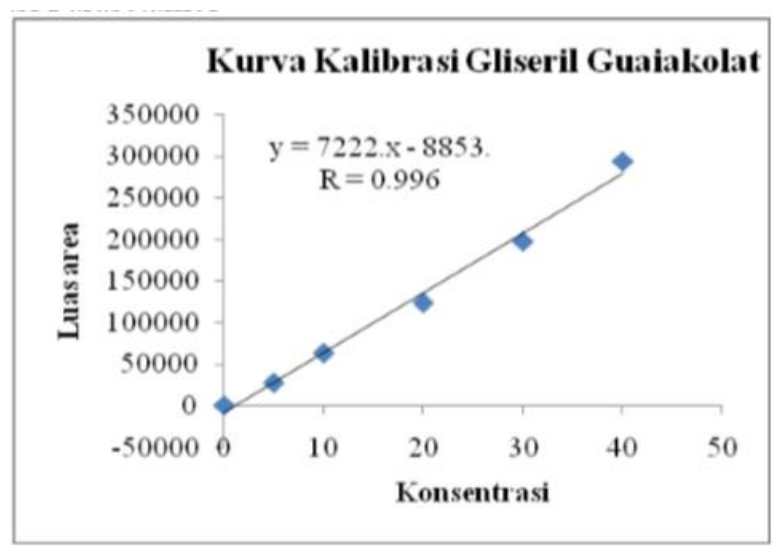

Fig. 6. Kurva Kalibrasi Gliseril Guaikolat

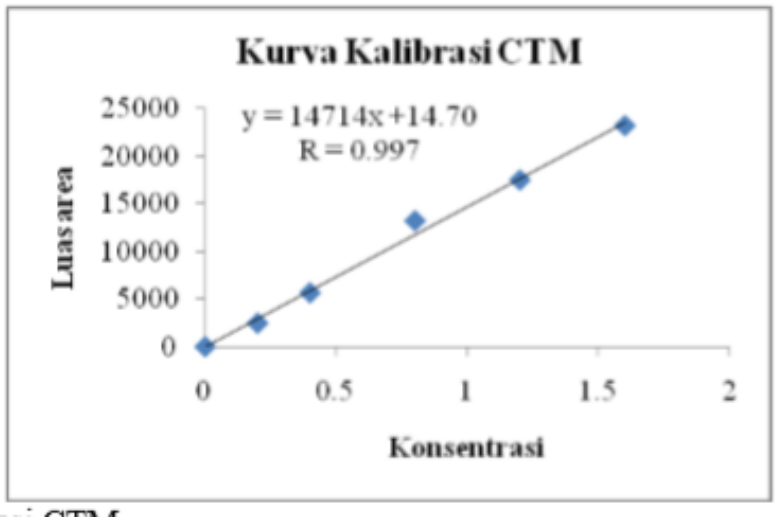

Fig. 7. Kurva Kalibrasi CTM

\subsection{Analisis Kuantitatif Sediaan Tablet Supraflu (PT. Kimia Farma)}

Table. 1. Data hasil perhitungan kadar campuran fenilefrin $\mathrm{HCl}$, parasetamol, gliseril guaiakolat dan klorfeniramin maleat dari sediaan tablet Supraflu® (P.T. Kimia Farma) setelah dilakukan uji statistik.

\begin{tabular}{ccccc}
\hline Sediaan & Fenilefrin HCl & Paracetamol & $\begin{array}{c}\text { Gliseril } \\
\text { Guaikolat }\end{array}$ & $\begin{array}{c}\text { Kloreniramin } \\
\text { Maleat }\end{array}$ \\
\hline Tablet Supraflu & $99,2362 \%$ & $96,0242 \%$ & $97,9870 \%$ & $101,4191 \%$ \\
(PT. Kimia Farma) & \pm & \pm & \pm & \pm \\
& $0,4493 \%$ & $0,2180 \%$ & $0,7435 \%$ & $0,7106 \%$ \\
\hline
\end{tabular}

\section{Kesimpulan}

Kondisi optimum hasil optimasi metode analisis penetapan kadar fenilefrin hidroklorida, parasetamol, gliseril guaiakolat dan klorfeniramin maleat secara simultan adalah dengan menggunakan perbandingan fase gerak metanol:buffer fosfat $\mathrm{pH} \mathrm{4,3} \mathrm{(60:40),} \mathrm{laju} \mathrm{alir} \mathrm{1,0} \mathrm{ml/menit} \mathrm{dan} \mathrm{dideteksi} \mathrm{pada} \mathrm{panjang} \mathrm{gelombang} 263 \mathrm{~nm}$. Hasil pemeriksaan kadar sediaan tablet yang beredar di pasaran yang mengandung campuran fenilefrin hidroklorida, parasetamol, gliseril guaiakolat dan klorfeniramin maleat menggunakan kondisi optimum diperoleh bahwa sediaan tablet Supraflu® (P.T. Kimia Farma) memenuhi persyaratan

\section{Referensi}

[1] Depkes RI. (1995). Farmakope Indonesia Edisi ke IV. Jakarta: Departemen Kesehatan Republik Indonesia. Hal. 210, 421, 649, 666, 1009.

[2] Kazakevich, Y., dan LoBrutto, R. (2007). HPLC for Pharmaceutical Scientists. New York: John Wiley and Sons Inc. Hal. 3-4, 15.

[3] Kromidas, S. (2006). HPLC Made to Measure A Practical Handbook for Optimization. Weinheim: Wiley-VCH Verlag GmbH \& Co. KgaA. Hal. 19-20.

[4] Meyer, V.R. (2004). Practical High-Performance Liquid Chromatography. Chichester: John Wiley and Sons Inc. Hal. 7-8, 15-16.

[5] Snyder, L.R., Joseph, J.K., dan Joseph, L.G. (2010). Practical HPLC Method Development. Edisi Kedua. New York: John Wiley \& Sons Inc. USP 30 and NF 25. (2007).

[6] The United States Pharmacopeia and The National Formulary. Edisi ke-30. New York: Electronic Version. 